\title{
Association Between Exclusive Breastfeeding and the Risk of Tonsilitis in Children Under Five in Demak, Central Java
}

\author{
Hendra Wardhana1), Ibnu Kharisman'), Paramita Stella²) \\ 1)Indonesian Doctor Internship Program, Sunan Kalijaga Hospital \\ 2)Indonesian Doctor Internship Program, Bagas Waras Hospital
}

\begin{abstract}
Background: Upper respiratory infection (URI) remains one of the primary causes of child mortality in Indonesia. Some studies have shown that exclusive breastfeeding can prevent various infectious diseases including URI. However, in some places the incidence of tonsilitis is still high although target of exclusive breastfeeding coverage has been met. This study aimed to determine association between exclusive breastfeeding and the risk of tonsillitis in children under five in Demak, Central Java.

Subjects and Method: This was a cross sectional study conducted at 3 Community Health Centers, Demak, Central Java, from March to April 2017. A sample of 35 children under five years old were selected for this study. The dependent variable was the incidence of tonsillitis. The independent variable was history of exclusive breastfeeding. The data were collected by questionnaire. Tonsillitis was determined by history taking and physical examination. The data were analyzed by Fisher exact test.
\end{abstract}

Results: Children without history of exclusive breastfeeding had an increased risk of contracting tonsillitis $(\mathrm{OR}=9.58 ; \mathrm{p}=0.015)$ compared to those with history of exclusive breastfeeding.

Conclusion: Provision of exclusive breastfeeding is associated with lower risk of tonsilitis in children under five.

Keywords: tonsillitis, exclusive breastfeeding, children under five

\section{Correspondence:}

Paramita Stella. Indonesian Doctor Internship Program, Bagas Waras Hospital, Klaten, Central Java.

\section{BACKGROUND}

Public health is an overall human development effort, community health development beginning with children's health efforts as early as possible (Ministry of Health RI, 2016). The majority of child deaths in Indonesia occur during the neonatal period. The time of child mortality is 19 per thousand during the neonatal period, 15 per thousand from 2 to 11 months and 10 per thousand from 1 to 5 years.

Although child mortality due to infection has dropped, child deaths due to infection are still the main spotlight of the government. Upper Respiratory Tract Infection (URTI) is the main source of infec- tion in children under 5 years of age followed by diarrhea, neurological diseases (meningitis and encephalitis) and typhoid fever. Tonsillitis often occurs in children under 5 years is mostly caused by bacteria or viruses. The process can be acute or chronic (UNICEF Indonesia, 2012; Basic Health Research, 2010).

Epidemiological data of Ear Nose and Throat (ENT) disease in seven provinces in Indonesia show chronic tonsillitis occupies the highest position after acute nasopharyngitis which is $3.8 \%$ (Sapitri, 2013; Rukmini, 2003; Farokah, 2007).

Tonsillitis is most common in subtropical countries. In cold climate countries the incidence is higher than that in tropical 
Indonesian Journal of Medicine (2018), 3(2): 71-76

https://doi.org/10.26911/theijmed.2018.03.02.02

countries, Streptococcus infection occurs throughout the year, especially in winter (Rusmarjono, 2003).

Based on data from Demak District Health Office, tonsillitis is included in the top 10 diseases in Primary Health Services. In order to reduce child morbidity and mortality, the United Nations Children Fund (UNICEF) and the World Health Organization (WHO) recommend exclusive breastfeeding (ASI) for a minimum of 6 months (Ministry of Health RI, 2014; WHO, 2016; Indonesia Health Profile, 2014).

Exclusive breastfeeding is not feeding babies with any food or drinks, including water, and only feed them with breast milk (except medicines and vitamin or mineral drops) exclusive limits if consumption other than breast milk is less than 100g/ day. If more than that, it is called partial. Exclusive breastfeeding coverage in Demak Regency in 2010 was $69.94 \%$, higher than the average national coverage of $55.7 \%$ and WHO target of 50\% (Public Health Office Demak, 2010; Ministry of Health RI, 2016; Data and Information Center RI, 2014; WHO, 2012; Da Costa et al., 2010; Ayton et al., 2015).

Various studies show exclusive breastfeeding is significant in preventing diarrhea, otitis media, multiple sclerosis, and acute respiratory infections. Also it prevents insignificantly in skin, urinary, ocular, and oral teeth diseases (Stapleton, 2010; Ladomenou et al., 2010; Agne et al., 2013; Hanieh et al., 2015). Studies in developing countries show babies who get formula milk are more often hospitalized than those who get exclusive breastfeeding. And babies who don't get breast milk are eight times more hospitalized than those who get breast milk (Lauer et al., 2006; Rinne et al., 2005; Satku, 2004; Agne et al.,
2013).

The achievement of exclusive breastfeeding coverage targets and the still high incidence of tonsillitis the reasons of the researchers to conduct a study to find out whether there is a relationship between the history of exclusive breastfeeding and the incidence of tonsillitis in children aged o to 5 years.

\section{SUBJECTS AND METHOD \\ 1. Study Design \\ This was an observational analytic with a cross sectional approach. The study was conducted at Demak 3 Community Health Center, Demak, Central Java.}

\section{Population and Samples}

A total of 35 children under 5 years of age was selected using consecutive sampling.

\section{Study Variables}

The dependent variable was tonsillitis. The independent variable was exclusive breastfeeding.

\section{Operational Definition of Variables}

Exclusive breastfeeding was defined as babies around less than 6 months old who only get breast milk without any other food except vitamins, drugs and minerals. The data were obtained from questionnaires from mothers of children. The measurement data was categorical, code o for exclusive breastfeeding and 1 for non-exclusive breastfeeding.

Tonsillitis was defined as inflammation of the tonsils. The diagnosis of tonsillitis was made if the tonsillar examination show that there were hypertrophy, detritus, hyperemia, edema, or exudate. Tonsillar enlargement could be expressed in $\mathrm{T} 1$ to $\mathrm{T} 4$ size. Cody \& Thane divides tonsil enlargement in the following sizes: $\mathrm{T} 1=$ medial limit of the tonsil through the anterior pillar to $1 / 4$ the distance of the anterior uvula pillar; T2 $=$ medial limit of the tonsil past $1 / 4$ the distance of the 
anterior-uvula pillar to $1 / 2$ distance of the anterior-uvula pillar; $\mathrm{T}_{3}=$ medial limit of the tonsil past $1 / 2$ distance of the anterioruvula pillar until arak the distance of the anterior-uvula pillar; $\mathrm{T} 4=$ the medial limit of the tonsils over the distance of the anterior-uvula pillar or more. (Herawati, 2003; Santoso et al., 2009; Siswantoro, 2003). The measurement data was continuous. For the purposes of analyzing the data, they were converted into dichotomy, code $\mathrm{o}$ for not tonsillitis and $\mathbf{1}$ for tonsillitis.

\section{Data Analysis}

The data were analyzed by using Fisher exact test through the SPSS 21.00 program.

\section{RESULTS}

The result of this study can be seen on Table 1. Table 1 showed the results of bivariate analysis about the relationship between exclusive breastfeeding and the incidence of tonsillitis. From the result of the research, 9 children (25.7\%) suffering from tonsillitis and 26 children $(74.3 \%)$ did not suffer from tonsillitis. Children who did not get exclusive breastfeeding were 27 children.

The results of bivariate analysis showed that children who did not get exclusive breastfeeding were 9.58 times more likely to experience tonsillitis than children who get exclusive breastfeeding.

Table 1. The relationship between exclusive breastfeeding and tonsillitis

\begin{tabular}{|c|c|c|c|c|c|c|c|c|}
\hline \multirow{2}{*}{$\begin{array}{c}\text { Exclusive } \\
\text { Breastfeeding }\end{array}$} & \multicolumn{2}{|c|}{ Tonsillitis } & \multicolumn{2}{|c|}{ Non Tonsillitis } & \multicolumn{2}{|c|}{ Total } & \multirow{2}{*}{ OR } & \multirow[b]{2}{*}{$\mathbf{p}$} \\
\hline & $\mathbf{n}$ & $\%$ & $\mathbf{n}$ & $\%$ & $\mathbf{n}$ & $\%$ & & \\
\hline No & 5 & 62.5 & 3 & 37.5 & 8 & 100 & 9.58 & 0.015 \\
\hline Yes & 4 & 14.8 & 23 & 85.2 & 27 & 100 & & \\
\hline Total & 9 & $25 \cdot 7$ & 26 & 74.3 & 35 & 100 & & \\
\hline
\end{tabular}

\section{DISCUSSIONS}

$\overline{\text { Based on the analysis results of the study by }}$ using an alternative test Fisher exact test, the score of $p=0.015$. This mean that there was a significant relationship between exclusive breastfeeding and the incidence of tonsillitis in children aged o to 5 years old. This study showed an Odds Ratio (OR) of 9.58 which mean that toddlers who did not get exclusive breastfeeding were 9.58 times more likely to have tonsillitis than toddlers who received exclusive breastfeeding.

The result of this study was in accordance with the theory of Stapleton (2010) which stated that breast milk was able to protect infants and children from infectious diseases, including those which have a significant effect, namely diarrhea, otitis media, multiple sclerosis, and respiratory infections. Breast milk also contained protein, fat, vitamins, minerals, hormones, enzymes, and growth factors that played a role in preventing the infection. Therefore, the babies who were exclusively breastfed would be healthier and did not get sick easily compared to babies who did not get exclusive breastfeeding.

The first 1-3 days of breast milk which called colostrum contained 1-17 times more immune substances than cooked milk in the form of maternal antibodies. In addition, there was also complete nutrition for babies, immune-regulators, and immune-modulators. Immune-modulator protection from exclusive breastfeeding could increase the secretory immunoglobulin A (sIgA). In addition, breast milk has a good effect on the good flora in the body of the newborn baby (Ladomenou et al., 2010).

The result of this study was in accordance with a study done by Elfia (2012) which stated that babies who got exclusive breastfeeding would be healthier and rarely experienced URTI compared to babies who 
did not get exclusive breastfeeding. The chi square statistical test results showed the score of $\mathrm{p}=0.024$, the strength level of the relationship was 0.346 . This study was in line with a study done by Noorhidayah and Sari (2014) which stated that exclusive breastfeeding was good because the toddlers got antibodies from breast milk and it could prevent the occurrence of URTI in toddlers.

This study has several limitations, which were the limitations of time and the number of cases, so that the number of samples used was the minimum number of samples for a study by using consecutive sampling, the researcher took the research subjects who fulfill the inclusion or exclusion criteria for a certain period. Based on epidemiological data on the incidence of tonsillitis in Indonesia, the incidence of tonsillitis occurred around 3.8\%.

Toddlers who did not receive exclusive breastfeeding were 9.58 times more likely to experience tonsillitis than children who were exclusively breastfed. Based on the previous studies, Communication, Information and Education (CIE) were needed for health service institutions to provide health counseling or health promotion to mothers especially those who have babies, toddlers, and children and also to further improve the quality services.

The community also need to know about health problems, especially regarding the tonsillitis in toddlers, as well as increasing the knowledge about health to pay more attention to the nutrition of their children in the future. Further research need to be done with larger samples, wider populations, and more controlling the external factors that could affect the results of the study.

\section{REFERENCES}

Agne Djigo A, Kwadjode KM, Idohou-
Dossou N, Diouf A, Guiro AT, Wade S (2013). Energy intake from human milk covers the requirement of 6 month old exclusively breastfed infants. The British Journal of Nutrition, 110(10), 1849-55.

Ayton J, Wills K, Hansen E, Nelson M. (2015). Cumulative risks and cessation of exclusive breast feeding: Australian cross-sectional survey. Arch Dis Child, 100: 863-868.

Da Costa THM, Haisma H, Wells JCK, et al. (2010). How much human milk do infants consume? Data from 12 countries using a standardized stable isotope methodology. Nutrition Journal 140:2227-2232.

Indonesian Health Department (2015). Dukung Ibu Bekerja Beri Asi Eksklusif. www.depkes.go.id/article.

Desai S, Scannapieco FA, Lepore M, Anolik R, Glick M (2008). Disease of the Respiratory Tract. In: Greenberg MS, Glick M, Ship JA, (eds). Burket's Oral Medicine. Hamilton, Ontario. Petrice Custance, 305-306.

Public Health Office Demak (2010). Draft Perencanaan Strategis 2011-2016. Dinas Kesehatan Kabupaten Demak.

Elfia, Yunita (2012). Hubungan Pemberian ASI Eksklusif dengan Kejadian ISPA pada bayi usia o-6 bulan di Puskesmas Ngresep Semarang. Fakultas Kedokteran UMS (online). Accessed on 20 March 2017.

Farokah, Suprihati, Suyitno S (2007). Hubungan Tonsilitis Kronis dengan Prestasi Belajar pada Siswa Kelas II Sekolah Dasar di Kota Semarang. Dalam: Riyanto WB (2007). Cermin Dunia Kedokteran No. 155 (THT), Jakarta, 34 (2).

Hanieh S, Ha TT, Simpson JA, Thuy TT, Khuong NC, Thoang DD, Tran TD (2015). Exclusive breast feeding in 
early infancy reduces the risk of inpatient admission for diarrhea and suspected pneumonia in rural Vietnam: a prospective cohort study. BMC Public Health 15:1166.

Herawati S, Rukmini S (2003). Penyakit Telinga Hidung Tenggorok. Dalam: Juwono (2003). Buku Ajar Ilmu Penyakit Telinga Hidung Tenggorok untuk Mahasiswa Fakultas Kedokteran Gigi. Jakarta. EGC.

Ministry of Health RI (2016). Profil Kesehatan Indonesia 2015.

Ladomenou F, Moschandreas J, Kafatos A, Tselentis Y, Galanakis E (2010). Protective effect of exclusive breastfeeding against infections during infancy: A prospective study. Archives of Disease in Childhood, 95(12): 1004.

Lakshman R, Ogilvie D, Ong KK (2009). Mothers' experiences of bottle-feeding : a systematic review of quailtative and quantitative studies. Arch Dis Child, 94(8):596-601.

Lauer JA, Betran AP, Barros AJ, de Onis M (2006). Deaths and years of life lost due to suboptimal breast-feeding among children in the developing world: a global ecological risk assessment. Public Health Nutrition, 9(6): 673-85.

Noorhidayah, Sari (2014). Hubungan Pemberian ASI Eksklusif dengan Kejadian ISPA pada Balita di Puskesmas Pekauman Banjarmasin. Sekolah Tinggi Ilmu Kesehatan (STIKes) Sari Mulia. Banjarmasin.

Nuzrina R, Roshita A, Basuki DN (2016). Factors affecting breastfeeding intention and its continuation among urban mothers in West Jakarta: a follow up qualitative study using critical point contact for breastfeeding. Asia Pacific Journal of Clinical Nutrition, 25(1):S43-S51.
Indonesian Health Profile (2014). Profil Kesehatan Indonesia Tahun 2014. Ministry of Health RI. ISBN 978-602235-911-1.

Data and Information Center RI (2014). Situasi dan Analisis ASI Eksklusif. Kementrian Kesehatan RI. Pusat Data dan Informasi.

Rinne MM, Gueimonde M, Kalliomaki M, Hoppu U, Salminen SJ, Isolauri E (2005). Similar bifidogenic effects of prebiotic-supplemented partially hydrolyzed infant formula and breastfeeding on infant gut microbiota. FEMS Medical Microbiology and Immunology. 43(1):59-65.

Basic Health Research (2010). Laporan Nasional Riset Kesehatan Dasar Tahun 2010. Badan Penelitian dan Pengembangan Kesehatan Departemen Kesehatan RI.

Rukmini S (2003). Buku Ajar Ilmu THT untuk Perawat. Edisi Pertama. Surabaya: FK Airlangga.

Rusmarjono (2003). Buku Ajar Ilmu Kesehatan THT Kepala Leher Edisi 5 . Jakarta: FKUI.

Rustam M (2010). Hubungan Pemberian ASI Eksklusif Terhadap Kejadian ISPA pada Bayi Usia 6-12 Bulan di Kabupaten Kampar, Provinsi Riau. Fakultas Kesehatan Masyarakat. PPS Epidemiologi. Depok.

Santoso O, Aditya W, Retnoningrum D (2009). Hubungan Kebersihan Mulut dan Gingivitis Ibu Hamil Terhadap Kejadian Bayi Berat Badan Lahir Rendah Kurang Bulan di RSUP Dr. Kariadi Semarang dan Jejaringnya. Artikel Penelitian. Media Medika Indonesiana, 43 (6).

Sapitri V (2013). Karakteristik Penderita Tonsilitis Kronis yang Diindikasikan Tonsilektomi di Bagian Tht Rumah Sakit Umum Raden Mattaher Jambi 
Indonesian Journal of Medicine (2018), 3(2): 71-76

https://doi.org/10.26911/theijmed.2018.03.02.02

pada Bulan Mei-Juli 2013. Jambi Medical Journal, 1(1).

Satku K (2004). Ministry of Health, Singapore Nursing Management of Oral Hygiene: Guidelines and Recommendations. MOH Nursing Clinical Practice Guidelines 1/2004, Singapore, 14-24.

Siswantoro B (2003). Pengaruh Tonsilektomi Terhadap Kejadian Bakterimia Pasca Operasi. Artikel Penelitian Bagian Ilmu Kesehatan THT-KL Fakultas Kedokteran Universitas Diponegoro/SMF Kesehatan THT-KL RS Dr. Kariadi, Semarang.

Stapleton FB (2010). Exclusive BreastFeeding Protects Infants Against Common Infections. Journal Watch.
Pediatrics \& Adolescent Medicine. UNICEF Indonesia (2012). Ringkasan Kajian Kesehatan Ibu dan Anak https://www.unicef.org/indonesia/id/A5_ -_B_Ringkasan_Kajian_Kesehatan_REV.pdf.

WHO (2016). Breastfeeding. http://www.who.int/topics/breastfeeding/en/. Accessed on 20 March 2017. (2012). World Health Assembly Nutrition Targets 2025: Breastfeeding Policy Brief. http://www.who.int/nutrition/publications/globaltargets2 025_policybrief_breastfeeding/en/. Accessed on 20 March 2017. 